\title{
SITUS NGURAWAN KECAMATAN DOLOPO KABUPATEN MADIUN (LATAR SEJARAH DAN UPAYA PELESTARIANNYA)
}

\author{
*Ike Fuadillah \& Soebijantoro
}

\begin{abstract}
Abstrak
Penelitian ini bertujuan untuk melihat gambaran tentang upaya pelestarian situs Ngurawan Kecamatan Dolopo Kabupaten Madiun serta sebagai media pembelajaran lokal bagi pendidikan sejarah. Penelitian ini menggunakan pendekatan kualitatif. Sumber data yang digunakan yaitu sumber datar primer dan sumber data sekunder. Teknik pengumpulan data menggunakan teknik wawancara, observasi dan dokumentasi. Validasi yang digunakan untuk menguji kebenaran dan keabsahan data menggunakan triangulasi sumber. Hasil penelitian yang diperoleh yaitu di Desa Ngurawan Kecamatan Dolopo Kabupaten Madiun terdapat Desa Wurawan yang meupakan sebutan kuno dari sebuah wilayah yang sekarang berada di daerah Madiun selatan, tepatnya sebuah dusun di Desa Dolopo Kecamatan Dolopo Kabupaten Madiun, yaitu Dusun Ngrawan. Penduduk Dusun Ngrawan mayoritas mata pencahariaan adalah petani. Selain itu berternak, berkebun dan sebagian membuat batu bata. Dalam aktivitas kesehariannya warga sering menemukan berbagai jenis benda purbakala, bahkan di dusun ini batu kuno berukuran besar terlihat banyak berserakan. Hal ini merupakan bukti bahwa dusun Ngrawan adalah sebuah dusun tua dan pusat peradaban pada masa kerajaan dahulu kala. Dari beberapa peneliti dan berbagai sumber sejarah yang ada menegaskan bahwa dusun Ngrawan adalah pusat kerajaan Glang-Glang i bumi Ngurawan di masa Singhasari dan Kadipaten Gegelang di Masa Kerajaan Majapahit.
\end{abstract}

\section{Kata Kunci: Situs Ngurawan, Latar Sejarah, Pelestarian Situs}

\section{Pendahuluan}

Masa lalu adalah kejadian yang telah terjadi pada masa lampau yang disusun berdasarkan peninggalan berbagai peristiwa sehingga menjadikan masa kini dapat dipahami oleh generasi penerus dari masyarakat terdahulu sebagai cermin untuk menuju kemajuan dalam kehidupan bermasyarakat, berbangsa dan bernegara. Peristiwa yang terjadi pada masa lampau akan memberi gambaran tentang kehidupan manusia dan kebudayaan di masa lampau sehingga dapat merumuskan hubungan sebab akibat mengapa suatu peristiwa dapat terjadi dalam kehidupan tersebut. Manusia dalam dinamika kehidupannya senantiasa hidup dengan hal-hal yang ditinggalkan baik disengaja maupun tidak di sengaja. Namun tidak semua masa lalu meninggalkan bukti atau jejak yang dapat digunakan oleh generasi sekarang dalam memahami dan mengambil nilai-nilainya untuk kehidupan masa kini dan masa mendatang, sebagai wujud adanya jejak sejarah peninggalan kebudayaan manusia. Peninggalanpeninggalan masa lalu ada yang letaknya terpusat dan tidak terpusat dalam suatu wilayah tertentu dalam jangka yang berjauhan. Tempat-tempat terpusat dapat disebut situs sejarah. Situs sendiri memiliki 
beberapa pengertian yang berbeda karena selain dunia komputer dan internet, di dalam dunia sejarah terdapat istilah situs.

Bila dalam dunia komputer dan internet merupakan website yaitu sebuah alamat yang kita kunjungi dan berisi informasi tertentu tentang pemilik website, maka kata situs dalam dunia sejarah berhubungan dengan tempat atau wilayah area. Situs adalah lokasi yang mengandung atau diduga mengandung benda cagar budaya termasuk lingkungan yang diperlukan bagi pengamananya.

Suatu hal penting yang perlu diketengahkan bahwa situs adalah sebagai sumber daya yang terbatas (finite), tak terbarui (non moveble), dan rapuh (Vulnereble/fragile), sehingga diperlukan penanganan situs secara tepat danbenar (http://www.riko.web.id/2013/12/pengert ian-situs-web.html diakses 15-04-2015).

Situs sejarah merupakan daerah dimana ditemukan benda-benda purbakala. Benda-benda purbakala bersejarah tersebut diantaranya istana-istana, makam, masjid dan candi. Dalam portal ini, benda-benda yang ditampilkan hanya yang berkaitan dengan sejarah. Oleh karena itu situs sejarah ini sangat penting untuk mempelajari dan memahami sejarah dan masyarakatIndonesia(http://melayuonline. com/ind/history/dig/3/situs-sejarah

diakses 15-04- 2015).

Manfaat situs sejarah adalah untuk memperkaya khasanah kebudayaan bangsa
Indonesia, menambah pendapatan negara karena digunakan sebagai obyek wisata, menyelamatkan keberadaan benda peninggalan sejarah sehingga dapat dinikmati oleh generasi mendatang dan membantu dunia pendidikan dan ilmu pengetahuan dengan memanfaatkan untuk obyek penelitian. Beberapa temuan situssitus di Indonesia, termasuk di Kabupaten Madiun pelestariannya sendiri ada yang terawat dan tidak terawat.

Situs tersebut merupakan cagar budaya sekaligus mendapat perhatian yang luar biasa dari masyarakat umum dan para sejarawan. Bahkan beberapa waktu lalu diadakan Festival Glang Glang. Namun tidak sedikit warga masyarakat Madiun dan sekitarnya yang belum mengetahui dan memahami tentang apa Situs Ngurawan, siapa yang menemukan Situs Ngurawan, dimana Situs Ngurawan tersebut ditemukan, kapan Situs Ngurwan ditemukan lalu bagaimana cerita sejarah dibalik ditemukannya Situs Ngurawan ini serta bagaimana upaya pelestariannya sehingga sampai saat ini menjadi perbincangan dikalangan peneliti sampai pada akhirnya menjadi suatu temuan yang fenomenal dalam kalangan penelitian. Oleh karena itu penelitian ini menarik untuk dilaksanakan.

\section{Tujuan Penelitian}

Dalam mengadakan penelitian tidak terlepas dari tujuan yang hendak dicapai, sebab tujuan penelitian akan memberi arah dalam penelitian. Adapun yang menjadi 
tujuan penelitian adalah Untuk menganilisis dan mendiskripsikan situs Ngurawan Kecamatan Dolopo Kabupaten Madiun, serta melihat gambaran yang lebih memadai tentang upaya pelestarian situs Ngurawan di Kecamatan Dolopo Kabupaten Madiun selama 2 tahun terakhir.

\section{Kajian Pustaka}

\section{A. Situs}

\section{Pengertian Situs}

Situs adalah lokasi yang mengandung atau diduga mengandung benda cagar budaya termasuk lingkungan yang diperlukan bagi pengamananya (Hatmadji dalam Berkala Arkeologi, 1993: 87). Situs sejarah dalam kaitanya dengan peninggalan sejarah atau warisan budaya yang disebut situs cagar budaya adalah lokasi yang mengandung benda cagar budaya, bangunan cagar budaya, atau struktur cagar budaya dan menyimpan informasi kegiatan manusia pada masa lalu (http://digilib.uns.ac.id/dokumen/detail /41785/ Penerapan-Good - Governance-

Di-Balai-Pelestarian-Situs-Manusia-

Purba-Sangiran-Bpsmps-Dalam-Upaya-

Pelestarian-Benda-Cagar-Budaya-Di-

Situs-Sangiran diakses 15-04-2015).

$$
\text { Undang-Undang Republik }
$$

Indonesia No 5 tahun 1992 tentang cagar budaya menyebutkan:

a. Bahwa cagar budaya merupakan kekayaan budaya yang penting. Artinya, bagi pemahaman dan pembangunan sejarah, ilmu pengetahuan dan kebudayaan, sehingga perlu dilindungi dan dilestarikan demi pemupukan kesadaran jati diri bangsa dan kepentingan nasional.

b. Bahwa untuk menjaga kelestarian benda cagar budaya diperlukan langkah pengaturan bagi penguasaan, pemilikan, penemuan, pencarian, pengelolaan, pemanfaatan dan penguasaan benda cagar budaya. Dari penjelasan tersebut dengan jelas dilindungi secara hokum. Artinya siapa yang merusak, mengambil dan menyimpan akan dikenai sanksi hukuman.

Selain itu, menurut undang-undang cagar budaya pasal 9 bahwa suatu tempat dikatakan memiliki nilai sejarah didorong oleh beberapa faktor diantaranya: a). Ditempat itu terdapat benda atau peninggalan sejarah, b). Merupakan tempat kelahiran, kemangkatan dan makam tokoh penting, c). Merupakan ajang dimana peristiwa penting tertentu terjadi (peristiwa sejarah), yang dalam disiplin ilmu sejarah disebut peristiwa pada masa lampau yang memiliki signifikasi sosial. Narasi sebuah situs sebagai narasi sejarah lokal mutlak dan sangat diperlukan. Hal ini disebabkan sejarah tidak hanya memiliki narasi besar (mayor) yang berkisar dengan seluruh 
tokoh-tokoh dengan seluruh tindakan historisnya. Sejarah juga banyak mengandung banyak serpihan yang mengandung banyak narasi kecil (minor) tentang bangunan dan seluruh pernikperniknya, kisah manusia di dalam kemelut persoalan politik, sosial, budaya dan hal-hal lain yang layak diketahui sebagai referensi bagi generasi muda.

Dalam konteks tersebut, situs-situs sejarah merupakan tanda secara semiotik dan faktual dapat dibaca untuk mengenali sosok sebuah kekuasaan dan tokohnya secara komprehensif (http://digilib.uns.ac.id/dokumen/jenis/ 10186/E-book diakses 15-04-2015).

Menurut uraian di atas mengenai pengertian situs adalah lokasi yang mengandung cagar budaya yang mampu memberikan makna pada kehidupan masa kini yang dapat menyimpan kegiatan manusia pada masa lalu. Situs sejarah yang berupa lingkungan alam dan benda-benda purbakala tetap berada pada satu kawasan. Situs-situs bersejarah yang mampu memberikan makna pada kehidupan masa kini adalah situs sejarah yang lingkungan alamnya dan benda-benda purbakalanya tetap berada pada satu kawasan.

Keutuhan antara lingkungan alam dan benda-benda purbakala itu yang justru dapat diserap generasi masa kini sebagai sumber inspirasi demi mewujudkan peradaban baru yang adiluhung (bermutu tinggi).

\section{Jenis-jenis Situs}

Situs purbakala dapat terbagi menjadi beberapa macam menurut periodesasi peninggalannya, antara lain: (1) Periodesasi masa pra sejarah terdiri dari situs peninggalan paliolitik, mesolitik, neolitik, dan megalithic. (2) Masa Hindhu-Budha (klasik) berupa bangunan candi, pura, gapura, benteng, lingga, yoni. (3) Periodesasi islam (Indonesia Madya). (4) Periodesasi kolonial (XVI-XIX) situs peninggalan dari zaman Belanda. (5) Masa kemerdekaan (1945-1949).

Dalam pengelolaan benda cagar budaya di Indonesia, perlu diidentifikasi jenis-jenis situs berdasarkan masanya atau periode waktunya yang meliputi: (1) Situs Prasejarah, (2) Situs Klasik, (3) Situs Islam, (4) Situs Kolonial (http://digilib.uns.ac.id/dokumen/jenis/ 10186/E-book diakses 15-04-2015).

Menurut uraian diatas mengenai pengertian situs adalah lokasi yang mengandung cagar budaya yang mampu memberikan makna pada kehidupan masa kini yang dapat menyimpan kegiatan manusia pada masa lalu. Situs sejarah yang berupa lingkungan alam dan benda-benda purbakala tetap berada pada satu kawasan. Keutuhan antara lingkungan alam dan benda-benda purbakala itulah yang justru dapat 
diserap generasi masa kini sebagai sumber inspirasi. Situs purbakala dapat dibagi menjadi beberapa macam yaitu berdasarkan bentuk fisik bangunan dan berdasarkan periodesasi mulai dari zaman prasejarah, hindhu-budha, islam, kolonial, dan masa kemerdekaan Indonesia. Pernyataan lokasi yang berada di darat dan/atau di air yang mengandung benda cagar budaya sebagai hasil kegiatan manusia atau bukti kejadian pada masa lalu.

Dalam hal ini sebuah situs cagar budaya merupakan lokasi yang dilindungi oleh peraturan pemerintah. Selain itu, juga memiliki perlindungan dari pihak-pihak resmi pemerintah. Sebuah lokasi dijadikan sebagai situs cagar budaya karena memiliki bukti peristiwa sejarah dan hasil dari aktivitas manusia pada masa lalu. Bukti-bukti sejarah ini masih dirawat dengan baik sebagai bagian dari sejarah perkembangan wilayah. Dalam sebuah lokasi ada yang memiliki lebih dari dua situs cagar budaya

\section{B. Definisi Latar Sejarah}

$$
\begin{aligned}
& \text { Menurut Kamus Besar Bahasa } \\
& \text { Indonesia pengertian latar adalah } \\
& \text { latar/la·tar/ n } 1 \text { permukaan; } 2 \text { halaman; } \\
& 3 \text { rata; datar; } 4 \text { dasar warna; } 5 \text { Sas } \\
& \text { keterangan mengenai waktu, ruang dan } \\
& \text { suasana terjadinya lakuan dalam karya } \\
& \text { sastra; } 6 \text { keadaan atau situasi (yang } \\
& \text { menyertai ujaran atau percakapan); } 7
\end{aligned}
$$

Sen dekor pemandangan yang dipakai dalam pementasan drama, seperti pengaturan tempat kejadian, perlengkapan dan pencahayaan (Diakses http://kbbi.web.id/latar 15-04-2015).

Dalam Kamus Besar Indonesia (1976: 329) latar adalah tempat dan waktu terjadi peristiwa dalam cerita. Kamus Besar Bahasa Indonesia (2008: 462) memberi definisi yang berbeda. Latar diberi definisi keterangan mengenai waktu, ruang, dan suasana terjadinya lakuan dalam karya sastra. Dari dua definisi tersebut, sekilas definisi kedua lebih lengkap dan lebih baik. Perbedaan keduanya terletak pada adanya suasana selain tempat dan waktu.

Untuk membahas lebih mendalam, definisi kamus saja kurang memadai untuk dijadikan dasar. Abrams menerangkan bahwa latar dari karya naratif atau drama adalah tempat secara umum dan waktu historis tindakan terjadi. Kenney (1966: 38) menjelaskan bahwa latar adalah elemen fiksi yang menunjukkan di mana dan kapan terjadi peristiwa. Dengan kata lain, istilah latar mengacu pada titik waktu dan ruang dari peristiwa-peristiwa dalam plot terjadi (diakseshttp://lokalbahasasastra.blogsp ot.com/2012/02/latar-setting.html 1504-2015).

Pada satu sisi, kata sejarah berasal dari Inggris yakni history (sejarah) dan berasal dari kata benda Yunani "Istoria" 
yang memiliki arti ilmu. Dalam penggunaannya oleh filsuf Yunani Aristoteles, Istoria berarti suatu penelaahan sistematis mengenai seperangkat gejala alam, entah susunan kronologis merupakan faktor atau tidak di dalam penelaahan, dalam hal ini penggunaan meskipun jarang tetapi masih tetap hidup di dalam Bahasa Inggris yang disebut "Natural history" (Louis Gottschalk dalam Ristiana dan Soebijantoro, 2014: 50).

Sejarah disini juga berasal dari bahasa arab yakni "Syajarah" yang memiliki makna pohon. Kata ini mulai masuk ke Indonesia sesudah terjadi akulturasi antara kebudayaan Indonesia dengan kebudayaan Islam dalam kaitan sejarah ini ternyata bermacam-macam pengertian "sejarah" yaitu silsilah, riwayat, babad, tambo ataupun tarikh. Silsilah yakni daftar atau asal usul, ranji keturunan, yang digambarkan secara skematis memang rupanya seperti pohon dengan cabang dan ranting-ranting.

Pengertian riwayat disini berasal dari arab yang memiliki arti lebih kurang sama dengan babad yang berasal dari Bahasa Jawa yang berarti riwayat kerajaan, riwayat bangsa, buku tahunan, kronik. Maksud buku tahunan adalah riwayat kerajaan, peristiwa dalam setiap tahun, sedangkan kronik merupakan cerita (fakta), peristiwa-peristiwa sejarah yang disusun menurut urutan waktu, tanpa menjelaskan hubungan antara peristiwa-peristiwa tersebut. Tarikh juga berasal dari Bahasa Arab yang berarti tahunan, kronik, perhitungan tahun, buku riwayat, tanggal atau pencatatan tanggal.

Sejarah dalam pandangan Ali (dalam Hamid dan Majid, 2011: 7) menegaskan bahwa sejarah yang Pertama, yakni merupakan jumlah perubahan-perubahan, kejadiankejadian, dan peristiwa-peristiwa dala kenyataan sekitar kita, Kedua, merupakan cerita tentang perubahanperubahan, dan Ketiga, merupakan ilmu yang bertugas menyelidiki tentang perubahan, pendapat lainnya (Hellet dalam Hamid dan Majid, 2011: 26) mendefinisikan sejarah sebagai suatu dialog yang tak berkesudahan antara sejarawan dengan masa lalunya dan sejarawan dengan sumber-sumbernya.

Pengertian sejarah adalah segala kejadian sepanjang masa. Segala kejadian tidak berarti bahwa semua kejadian dicatat dalam sejarah, tetapi yang terbatas yang ada hubungannya dalam tata kehidupan dengan manusia. Peristiwa sejarah bukanlah kejadian atau peristiwa perorangan, yang tidak menyangkut sebagian besar orang (manusia) sehingga dengan kejadian itu tidak menimbulkan perubahan struktur ekonomi, sosial, politik dan kebudayaan dari pada sekelompok manusia yang 
hidup di daerah yang dalam batas-batas tertentu cukup luas (Sutrasno,1975: 7).

Dari beberapa pengertian sejarah tersebut dapat disimpulkan bahwa pengertian latar sejarah adalah tempat dan waktu terjadinya peristiwa dimana disebut dengan asal usul suatu kejadian peristiwa yang benar-benar terjadi pada masa lampau atau juga disebut riwayat sehingga dapat menjadi pedoman hidup atau reverensi hidup bagi sebuah bangsa. Dasar proses dan bentuk pengisahan atas apa yang telah terjadi pada masa lampau yang disusun berdasarkan pada peninggalan berbagai peristiwa.

Pada masa kini akan dapat dipahami oleh generasi penerus dari masyarakat terdahulu sebagai cermin untuk menuju kemajuan dalam kehidupan bermasyarakat, berbangsa dan bernegara. Peristiwa yang terjadi pada masa lampau akan memberi kita gambaran tentang kehidupan manusia dan kebudayaan di masa lampau sehingga dapat merumuskan hubungan sebab akibat mengapa suatu peristiwa dapat terjadi dalam kehidupan sehingga memberikan pemahaman terhadap suatu kejadian dan dijadikan acuan terhadap suatu permasalahan

\section{Upaya Pelestarian Situs}

1. Pengertian Pelestarian Situs

Pelestarian adalah upaya dinamis untuk mempertahankan keberadaan cagar budaya dan nilainya dengan cara melindungi, mengembangkan dan memanfaatkannya (Undang-Undang Republik Indonesia Nomor 11 Tahun 2010 Tentang cagar Budaya 2010: 5).

Selain itu, konservasi perlu dilakukan sebagai usaha pelestarian agar budaya tersebut tidak hilang (Benny Kurniawan 2012: 91). Pelestarian menjadi penting mengingat dengan adanya pelestarian budaya maka budaya budaya yang dahulu pernah ada akan tetap berkembang dan terpelihara keberadaanya (Prastyo dan Hartono dalam jurnal Agastya, 2014: 84). Selanjutnya Abraham Nurcahyo (dalam jurnal Agastya, 2009: 131) mengungkapkan fungsi pelestarian diarahkan pada pengenalan dan pendalaman nilai-nilai luhur budaya bangsa, sehingga diharapkan dapat menumbuhkan dan memperkokoh rasa cinta tanah air dan kebanggaan nasional.

Masa kini peninggalan-peninggalan masa lampau baik berupa fisik maupun non fisik banyak yang terabaikan. Hal tersebut dikarenakan masih banyak masyarakat yang kurang sadar akan pentingnya pelestarian peninggalan masa lampau. Sehingga masyarakat yang sadar akan selalu menjaga dan merasa bertanggung jawab terhadap pelestarian masa lalu (Abraham Nurcahyo dalam jurnal Agastya 2012 : 29). Secara umum, pengertian pelestarian adalah upaya mempertahankan keadaan asli, dengan 
tidak merubah yang ada dan tetap mempertahankan kelangsungan kondisinya yang sekarang.

Lebih lanjut "pelestarian" juga mempunyai pengertian perlindungan atau pemeliharaan dari kemusnahan dan atau kerusakan. Pelestarian tersebut dapat tercapai melalui berbagai upaya pemugaran seperti konservasi atau rekonstruksi. Pelestarian merupakan kegiatan penting dan utama, sebab tanpa pelestarian maka kegiatan pembinaan dan pemanfaatan tidak dapat dilaksanakan. Oleh karena itu, upaya penyelamatan data pelestarian sumber daya arkeologi perlu mendapat perhatian utama untuk dikembangkan dan dimasyarakatkan (Kusumahartono dalam Balai Konservasi Peninggalan Borubudur, 2009: 11).

2. Usaha Pelestarian Situs

$$
\text { Menurut Undang-Undang }
$$

Republik Indonesia Nomor 11 Tahun 2010 Tentang Cagar Budaya, Pelestarian cagar budaya berasaskan pada:
a. Pancasila;
b. Bninneka Tunggal Ika;
c. Kenusantaraan;
d. Keadilan;
e. Ketertibaan dan kepastian hukum;
f. Kemanfaatan;
g. Keberlanjutan;
h. Partisipasi;
i. Transparasi dan akuntabilitas.

Sedangkan untuk tujuan pelestarian adalah:

a. Melestarikan warisan budaya bangsa dan warisan umat manusia;

b. Meningkatkan harkat dan martabat bangsa;

c. Memperkuat kepribadian bangsa;

d. Meningkatkan kesejahteraan rakyat;

e. Mempromosikan warisan budaya bangsa kepada masyarakat internasional.

Upaya pelestarian situs diwujudkan dalam aktivitas pelestarian benda cagar budaya. Pelestarian ini dilakukan dalam bentuk aktvitas. Aktivitas yang meliputi pemeliharaan, perawatan dan pemugaran. Aktivitas pemeliharaan dilakukan antara lain dengan membersihkan dari kotoran debu dan sampah. Aktivitas perawatan dilakukan dengan mengusahakan agar komponen penyusun berada pada posisi yang seharusnya, sehingga fungsi komponen tersebut dapat diaktualisasikan secara penuh.

Aktivasi pemugaran dilakukan dengan cara membangun kembali sesuai kondisi yang asli, sehingga aktivitas pemugaran perlu dilaksanakan apabila ada kerusakan yang sangat parah (Suranto dalam BKPB, 2008: 5). Peninggalan-peninggalan situs dapat mempunyai arti besar sebagai kebangsaan nasioal dan dapat memperkuat perasaan kebangsaan. 
Kondisi ini menyebabkan pemugaran candi-candi menjadi suatu keharusan. Hal ini tidak berati bahwa seseorang yang mempunyai banyak uang, kemudian dapat datang ke sini, memanggil pemborong dan memperbaki candi atau situs lainnya.

Namun demikian ada syarat yang harus dipenuhi Pertama, pemugaran harus dilakukan oleh Derektorat Sejarah dan Purbakala. Dana datang dari pemerintah atau dari sumbangansumbangan pihak swasta. Kedua, dilakukan pemugaran selain untuk menghindarkan kerusakan, juga bertujuan untuk mengembalikan peninggalan itu pada bentuk asli. Sebelum dilakukan pemugaran bangunan, harus dipelajari dulu secara teliti bangunan yang aslinya, agar hasil pemugaran benar-benar serupa dengan bangunan itu waktu masih berdiri.

Ketiga, tambahan yang dapat diadakan ialah tambahan-tambahan kecil pada tempat-tempat yang dapat ditentukan dengan pasti, bahwa hiasan itu benar-benar ditempat itu. Hal yang perlu dicatat bahwa:

a. Bentuk dan ukurannya tepat pada aslinya.

b. Dapat ditemukan orang ahli yang memiliki ketrampilan untuk melakukan pekerjaan itu. c. Dipasangkan pemberitahuan dengan tanda-tanda bahwa hiasan itu tambahan.

Dengan dasar-dasar diatas memungkinkan peninggalan-peninggalan bersejarah tersebut dapat menarik lebih banyak perhatian dari masyarakat. Kesadaran sejarah bangsa pada dasarnya akan membawa pada rasa persatuan yang berakar pada dimilikinya riwayat bersama, sehingga memberikan landasan pada cita-cita bersama untuk mencapai suatu masa depan yang merupakan berkelanjutan masa lalu dan harus dipersiapkan dimasa kini.

Oleh karena itu, nilai-nilai kehidupan masa lalu harus terus digali untuk menegakkan martabat bangsa sekarang dan sebaliknya apabila membangun atas dasar kepalsuan berarti menjerumuskan generasi yang datang. Mengingat hal tersebut, maka dewasa ini peninggalan arkeologi juga sepatutnya dipandang sebagai sebuah sumber daya, yaitu sumber daya arkeologi maka harus diteliti dan dilestarikan (Mahmud dan Mas'ud, 2002: 6).

Berdasarkan uraian diatas dapat disimpulkan, pelestarian adalah usaha untuk mempertahankan keadaan asli dengan tidak mengubah yang ada dan tetap mempertahankan kelangsungan konsistensinya sekarang serta upaya perlindungan dari adanya bahaya kemusnahan agar tetap berpenampilan 
baik, bersih terjaga dan terawat keberadaanya.

Perkembangan dan kemajuan teknologi semakin menggeser kebudayaan daerah. Kondisi ini mengharuskan generasi muda hendaknya ikut menjaga dan melestarikan budaya daerah karena budaya daerah merupakan akar dari munculnya budaya nasional. Pentingnya upaya pelestarian sebagaimanaa dilihat bahwa sebuah budaya kearifan lokal menegaskan eksistensi dari nilai-nilai luhur yang menjadi jati diri bangsa. Boleh dikatakan bahwa keragaman peninggalan arkeologis diseluruh wilayah Indonesia merupakan elemen bagi pilar kebudayaan nasional.

Keberadaan potensi situs dan artefak disuatu tempat/daerah merupakan milik masyarakat di sekitarnya. Oleh karena itu, masyarakat lokal dengan sendirinya memiliki hak azazi untuk menginterpretasikan, memelihara dan mengelola sumberdaya arkeologi bagi pembangunan bangsa pada umumnya lebih khusus masyarakat disekitar.

Berpedoman pada berbagai uraian diatas, maka peninggalan arkeologi harus diteliti dan dilestarikan karena bermanfaat pada masa kini dan masa yang datang, baik di bidang ideologi, akademi, ekonomi dan diplomasi

\section{Metode Penelitian}

\section{A. Lokasi dan Waktu Penelitian}

Penelitian ini dilaksanakan di Desa Ngurawan Kecamatan. Dolopo Kabupaten Madiun yang mana tempat tersebut merupakan letak situs Ngurawan dan sejarahnya Penelitian ini dilaksanakan selama 6 bulan yaitu mulai bulan Februari sampai Juli 2015.

\section{B. Pendekatan dan Jenis Penelitian}

Penelitian ini menggunakan pendekatan kualitatif. Pendekatan kualitatif merupakan metode penelitian yang digunakan untuk meneliti pada kondisi obyek yang alamiah, dimana peneliti adalah sebagai instrumen utama, teknik pengumpulan data dilakukan secara trianggulasi, analisis data bersifat induktif, dan hasil penelitian kualitatif menekan pada makna (Sugiyono, 2008: 402-405). Pada dasarnya penelitian kualitatif digunakan dalam penelitian yang merujuk pada objek dan fenomena yang terjadi secara alami.

Adapun data yang akan diperoleh akan bersifat deskriptif karena menggunakan pendekatan induktif. Penelitian ini menggunakan pendekatan induktif yang mana peneliti melakukan pengamatan atas permasalahan khusus yang ada di Desa Ngurawan Kecamatan Dolopo Kabupaten Madiun tempat berlangsungnya sejarah situs Ngurawan. Selanjutnya menarik kesimpulan secara umum dengan dukungan dari beberapa 
informasi, sehingga data yang akan diperoleh akan bersifat deskriptif. Jenis penelitian yang dilakukan yaitu jenis penelitian deskriptif. Deskriptif dalam catatan data ini meliputi potret subjek, rekonstruksi dialog, deskripsi keadaan fisik, struktur tentang tempat, dan barang lain yang ada di sekitarnya.

Demikian juga, catatan tentang berbagai peristiwa khusus (termasuk siapa yang terlibat dengan cara bagaimana, gerak-geriknya, dan juga tingkah laku atau sikap penelitiannya) (Sutopo, 2002: 74). Pendekatan ini cocok untuk meneliti tentang sejarah Situs Ngurawan sebagai sumber pembelajaran sejarah lokal. Penelitian ini dilaksanakan dengan menganalisis data yang diperoleh dari wawancara, dokumentasi, dan observasi langsung di lapangan.

\section{Sumber Data dan Teknik Pengambilan}

\section{Sampel}

\section{Sumber Data}

Menurut Lofland dan Lofland dalam Moleong (2012: 157), sumber data utama dalam penelitian kualitatif ialah kata dan tindakan, selebihnya adalah data tambahan seperti dokumen dan lain-lainnya. Sumber data penelitian ini merupakan sumber data primer dan sumber data sekunder yang dapat menjelaskan informasi yang diperlukan dalam penelitian. Sumber data pada penulisan ini diperoleh dari:

a. Sumber data primer

Sumber data primer merupakan sumber data yang diperoleh secara langsung dari sumber asli atau tidak melalui perantara. Data-data primer berupa opini informan utama, hasil observasi terhadap suatu benda fisik maupun hasil pengujian (Amin, 2003: 57). Hal senada juga disampaikan oleh Umar (2011: 42) bahwa data primer merupakan data yang diperoleh dari sumber pertama baik dari individu atau perseorangan seperti hasil dari wawancara atau hasil pengisian kuisioner yang biasa dilakukan oleh peneliti.

Data yang didapat berupa hasil wawancara dengan informan. Sumber lisan dapat diperoleh dengan mendeskripsikan secara tertulis hasil pengamatan atau wawancara yang dilakukan. Informan dari penelitian ini yaitu juru kunci situs Ngurawan atau orang yang dianggap ikut serta dalam pembangunan dan mengetahui secara langsung sejarah situs Ngurawan

b. Sumber data sekunder

Sumber data sekunder menurut Amin (2003: 57) adalah data penelitian yang diperoleh peneliti 
secara tidak langsung atau melalui media perantara yang diperoleh maupun dicatat oleh pihak lain. Sumber data sekunder yang digunakan dalam penelitian ini adalah profil kelurahan di desa Ngurawan Kecamatan. Dolopo Kabupaten Madiun

\section{Teknik Pengumpulan Data}

Menurut Sugiyono (2008: 224) teknik pengumpulan data merupakan langkah yang paling strategis dalam penelitian, karena tujuan utama dari penelitian adalah mendapatkan data. Tanpa mengetahui teknik pengumpulan data, maka peneliti tidak akan mendapatkan data yang memenuhi standar data yang ditetapkan. Pengumpulan data dalam penelitian ini dilakukan dengan wawancara, observasi, dan dokumentasi tertulis/arsip.

1. Wawancara

Nazir (2009: 193-194) berpendapat bahwa wawancara merupakan proses memperoleh keterangan untuk tujuan penelitian dengan cara tanya jawab, sambil bertatap muka antara si penanya atau pewawancara dengan si penjawab atau responden dengan menggunakan alat yang dinamakan interview guide (panduan wawancara).

Hal serupa juga diungkap oleh Esterberg (dalam Sugiyono, 2008: 231) wawancara adalah pertemuan dua orang untuk bertukar informasi dan ide melalui tanya jawab, sehingga dapat dikonstruksikan makna dalam suatu topik tertentu.

Wawancara dikelompokkan menjadi beberapa bentuk dalam melakukan komunikasi lisan yaitu berupa bentuk terstruktur, semiterstruktur, dan tidak terstruktur (Sugiyono, 2008: 233). Penelitian yang dilakukan menggunakan jenis wawancara tidak terstruktur. Artinya, pedoman wawancara yang digunakan berupa garis-garis besar permasalahan yang akan digunakan.

Metode tersebut digunakan dalam penelitian ini dikarenakan peneliti akan melakukan wawancara kepada informan yang dianggap sebagai salah satu sumber yang bisa menjawab rumusan masalah penelitian. Peneliti perlu menjelaskan kepada responden tentang dan tujuan penelitian ini. Sebelum wawancara, terlebih dahulu menyusun pedoman wawancara sebagai salah satu kode etik wawancara.

2. Observasi Langsung

Menurut Nasution (dalam Sugiyono, 2008: 228) menyatakan bahwa observasi adalah dasar semua ilmu pengetahuan. Para ilmuwan hanya dapat bekerja berdasarkan data, yaitu fakta mengenai dunia kenyataan yang diperoleh melalui alat 
yang sangat canggih. Benda-benda yang sangat kecil (proton dan elektron) maupun yang sangat jauh (benda ruang angkasa) dapat diobservasi dengan jelas.

Hal senada juga disampaikan oleh Nazir (2009: 175) observasi langsung atau dengan pengamatan langsung adalah cara pengambilan data dengan menggunakan mata tanpa ada pertolongan alat standar lain untuk keperluan tersebut. Teknik observasi digunakan untuk menggali data dari sumber data yang berupa peristiwa, tempat atau lokasi dan benda serta tekanan gambar yang dilakukan secara langsung maupun tidak langsung. Terdapat dua jenis observasi, yakni observasi partisipan dan obsevasi non-partisipan.

Jenis observasi yang dipilih peneliti yakni observasi nonpartisipan. Peneliti tidak ikut di dalam kehidupan obyek yang akan diobservasi dan secara terpisah berkedudukan selaku pengamat. Di dalam hal ini peneliti hanya bertindak sebagai penonton saja tanpa harus ikut terjun langsung ke dalam acara. Pada observasi ini peneliti mendatangi peristiwanya. Kehadiran dan peran peneliti di lokasi bersifat pasif, sebab kehadirannya sebagi orang asing diketahui oleh yang diamati, dan bagaimanapun hal itu membawa pengaruh pada yang diamati. Tujuan observasi ini adalah untuk melihat serta mengamati bagaimana sejarah situs Ngurawan. Hal-hal yang perlu diamati atau diobservasi diantaranya yaitu latar belakang sejarah, kapan terjadinya situs Ngurawan, Siapa yang menemukan pertama kalinnya situs Ngurawan, nilai-nilai filosofis yang terkandung di dalam penemuan situs Ngurawan serta pihak yang terlibat didalamnya, serta potensinya sebagai sumber pembelajaran sejarah lokal

3. Dokumentasi

Metode dokumentasi yaitu pengambilan data yang diperoleh melalui dokumen-dokumen (Usman dan Setiadi, 2003: 73). Metode ini salah satu cara yang memudahkan dalam kegiatan penelitian, karena dalam melakukan penelitian harus ada sumber yang relevan dan mendukung sehingga penelitian yang dilakukan dapat berjalan lancar. Jenis dokumentasi yang dipilih dalam penelitian ini yaitu dokumentasi primer dan dokumentasi sekunder.

Dokumentasi primer diperoleh melalui hasil observasi dan hasil wawancara. Hasil observasi yang diperoleh berupa hasil pengamatan langsung oleh peneliti yang kemudian dideskripsikan dalam penelitian ini. Hasil dari kegiatan wawancara berupa 
keterangan dalam bentuk rekaman yang diubah dalam bentuk tulisan oleh peneliti. Selain sumber primer, adapula sumber sekunder yang dipakai dalam penelitian ini. Sumber sekunder yang didapat berasal dari sumber yang diambil selain manusia, diantaranya profil Kelurahan di desa Ngurawan Kecamatan Dolopo Kabupaten Madiun.

\section{E. Prosedur Penelitian}

Penelitian ini dilakukan selama 6 bulan. Penelitian dilaksanakan mulai dari bulan Februari sampai dengan bulan Juli tahun 2015. Tahapan dalam penelitian ini tersusun sebagai berikut:

\section{Tahap Persiapan}

Tahap awal dari penelitian ini merupakan bagian dari menetapkan fokus penelitian. Kegiatan ini dimulai dengan menetapkan tema dan judul yang akan menjadi obyek penelitian. Termasuk di dalamnya yaitu dengan menentukan lokasi penelitian. Selain itu peneliti juga melakukan perizinan kepada pengelola obyek tersebut. Hal ini dilakukan agar tidak menimbulkan perbedaan pemahaman antara peneliti dan subyeknya. Selain itu juga mempermudah prosedur dalam melakukan penelitian selanjutnya.

Kemudian setelah menentukan tema dan judul, peneliti berkonsultasi tentang tema dan judul tersebut kepada dosen pembimbing.
Selanjutnya, menjelaskan tentang kondisi awal dari obyek penelitian. Setelah mendapatkan persetujuan maka peneliti mulai melakukan kegiatan penelitian awal.

2. Tahap Penelitian

Tahapan yang selanjutnya merupakan tahapan penelitian. Pada tahap ini dilakukan pengumpulan data, pengolahan data, dan analisis data. Dalam tahap pengumpulan data peneliti mendapatkan data dari berbagai sumber. Sumber yang didapat merupakan hasil dari wawancara, sumber dokumen, dan pengamatan atau observasi secara langsung. Data yang terkumpul akan mampu diolah secara baik dan benar oleh peneliti.

Pengolahan data digunakan untuk mendapatkan deskripsi awal obyek penelitian. Setelah itu dilakukan analisis data untuk mempermudah dan mendapatkan validitas dari hasil data yang diperoleh. Tujuan analisis data memperdalam hasil temuan data yang diperoleh dan mampu mengetahui hasil awal sesuai dengan tujuannya. Apabila diketemukan hasil yang tidak sesuai maka akan dilakukan analisis berkelanjutan. Hal ini dilakukan agar hasil penelitian benar-benar maksimal dan sesuai kenyataan. 
3. Tahap Laporan

Pada tahap akhir merupakan tahap penyelesaian laporan atau penyajian data. Penyusunan laporan didasarkan hasil analisis data yang sudah didapatkan pada tahap sebelumnya. Laporan dilakukan secara benar dan tersusun sistematis. data yang disajikan merupakan data yang sesuai dengan fakta dan dapat dipertanggungjawabkan.

Kesalahan dalam laporan penelitian umumnya dilakukan yaitu laporan yang tidak tersusun secara sistematis dan penyajian data kesimpulan tidak sesuai dengan fakta yang didapat pada saat penelitian. Untuk menghindari hal itu, penyajian data harus sesuai dengan analisis data yang dilakukan. Artinya peneliti harus benar-benar teliti dan mampu untuk dapat menyajikan data secara aktual.

\section{F. Teknik Keabsahan Data}

Untuk mendapatkan data yang valid dalam penelitian ini, peneliti menggunakan teknik validitas data sebagai berikut:

1. Triangulasi metode adalah pengumpulan data yang sama dengan menggunakan metode pengumpulan data yang berbeda, serta diusahakan mengarah pada sumber data yang sama untuk menguji kemantapan informasi. Penggunaan metode pengumpulan data yang berbeda, bahkan lebih jelas diusahakan mengarah pada sumber data yang sama untuk menguji kemantapan informasi. Misalnya, memantapkan validitas data mengenai suatu keterampilan seseorang dalam bidang tertentu. Peneliti bisa menggunakan metode pengumpulan data berupa kuesioner. Kemudian dilakukan wawancara mendalam pada informan yang sama dan hasilnya diuji dengam pengumpulan data sejenis dengan menggunakan teknik observasi pada saat orang tersebut melakukan kegiatannya atau perilakunya (Sutopo, 2002: 80).

2. Triangulasi sumber data adalah mengumpulkan data dari berbagai sumber data digunakan untuk menguji kebenaran tentang pelaksanaan pembelajaran bahasa Indonesia. Cara ini mengarahkan peneliti agar di dalam mengumpulkan data, wajib menggunakan beragam sumber data yang tersedia. Artinya, data yang sama atau sejenis akan lebih mantap kebenarannya bila digali dari beberapa sumber data yang berbeda. Triangulasi sumber data yang memanfaatkan jenis sumber data yang berbeda-beda untuk menggali data yang sejenis (Sutopo, 2002: 79). 
3. Review informan merupakan usaha pengembangan validitas penelitian. Digunakan untuk mereviu informan, apakah data hasil wawancara sudah valid dan sesuai dengan kesepakatan atau belum. Pada waktu peneliti sudah mendapatkan data yang cukup lengkap dan belum utuh dan menyeluruh, maka unit-unit laporan yang telah disusunnya perlu dikomunikasikan dengan informannya, khususnya yang dipandang sebagai informan utama (Sutopo, 2002: 83).

Adapun secara singkat teknik trianggulasi sumber dapat dilihat dari bagan di bawah ini:

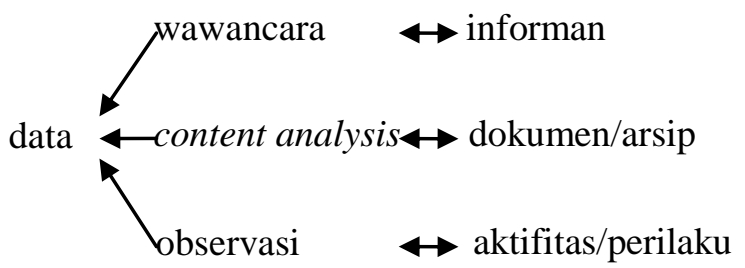

Bagan 3. 1. Trianggulasi Sumber (Sutopo, 2002: 80)

\section{G. Teknik Analisis Data}

Analisis data adalah proses analisis data dimulai dengan menelaah seluruh data yang tersediadari berbagai sumber yaitu wawancara, pengamatan yang sudah dituliskan dalam catatan lapangan, dokumen pribadi, dokumen resmi, gambar, foto, dan sebagainya (Moleong, 2011: 247). Lebih lanjut, Miles dan Huberman (dalam Sugiyono, 2008: 246-253) mengemukakan bahwa dalam analisis data kualitatif dilakukan secara interaktif dan berlangsung secara terus menerus melalui reduksi data (data reduction), penyajian data (data display) dan penarikan kesimpulan (conclusion drawing atau verification).

1. Tahap Reduksi data

Dalam tahap reduksi data, peneliti melakukan proses seleksi, pemfokusan, penyederhanaan dan abstraksi data dari sumber penelitian. Reduksi data merupakan bagian dari proses analisis yang mempertegas, memperpendek, membuat fokus, membuang hal-hal yang tidak penting dan mengatur data sedemikian rupa sehingga simpulan penelitian dapat dilakukan. Peneliti melakukan tahap reduksi data dengan membaca secara cermat objek penelitian dan kemudian dibagi ke dalam kategori sesuai kajian yang peneliti amati.

2. Tahap Penyajian Data

Sajian data merupakan suatu rakitan organisasi informasi, deskripsi dalam bentuk narasi yang memungkinkan simpulan penelitian dapat dilakukan. Sajian ini merupakan rangkaian kalimat yang disusun secara logis dan sistematis. Tujuannya agar peneliti bisa memahami objek yang diteliti dan memberikan jawaban sesuai rumusan masalah penelitiannya. Hubungannya dengan tahap penyajian data, peneliti melakukan ringkasan yang relevan 
dengan bidang kajian yang diteliti. Hal ini dilakukan agar memudahkan peneliti dalam mengelompokkan dan menentukan simpulan.

3. Tahap Penarikan Kesimpulan

Tahap simpulan merupakan tahap akhir dalam analisis data ini. Berbagai data yang dibutuhkan untuk penarikan suatu simpulan mulai di analisis secara lebih mendalam. Hal ini dilakukan agar penelitian kualitatif ini bisa dipertanggungjawabkan kebenarannya. Di samping itu, adanya data-data yang dikumpulkan dapat dijadikan suatu pertimbangan yang akan menentukan arah suatu kajian yang diteliti.

Oleh karena itu dalam tahapan yang dilakukan merupakan suatu rangkaian tahapan yang memiliki keterkaitan. Adapun keterkaitan komponen antara tahap tersebut sebagai berikut:

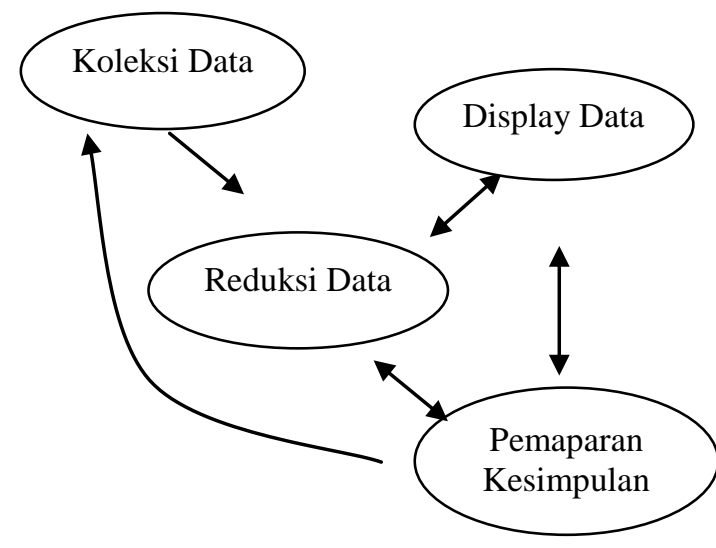

Bagan 3. 2. Analisis Data Model Interaktif, Miles dan Huberman
(Sumber: Milles and Hubberman, 1992: 20)

\section{Hasil Penelitian}

\section{A. Situs Ngurawan Kecamatan Dolopo Kabupaten Madiun}

Ngurawan atau Wurawan adalah sebutan kuno dan sebuah wilayah yang sekarang letaknya berada di daerah Madiun selatan, tepatnya sebuah dusun di Desa Dolopo Kecamatan Dolopo Kabupaten Madiun, yaitu Dusun Ngrawan. Butuh waktu 45 menit dari pusat kota untuk mencapainya.

Daerah ini cukup mudah dijangkau transportasi lantaran berada di jalur utama Madiun-Ponorogo. Penduduk Dusun Ngrawan mayoritas adalah petani, disamping bertani mereka juga berternak, berkebun dan sebagian membuat batu bata, dalam aktivitas kesehariannya warga sering menemukan berbagai jenis benda purbakala, bahkan di dusun ini batu kuno berukuran besar terlihat banyak berserakan di mana-mana.

Hal ini membuktikan bahwa Dusun Ngrawan adalah sebuah dusun tua dan pusat peradaban pada masa kerajaan dahulu kala. Dari beberapa peneliti dan berbagai sumber sejarah yang ada menegaskan bahwa dusun Ngrawan adalah pusat kerajaan Glang-Glang $i$ bumi Ngurawan di masa Singhasari dan Kadipaten Gegelang di Masa Kerajaan Majapahit. 


\section{B. Upaya Pelestarian Situs Ngurawan} Kecamatan Dolopo Kabupaten Madiun

Upaya pelestarian yang telah dilakukan dahulu dan sekarang pada dasarnya mempunyai tujuan yang sama, yaitu pelestarian demi kepentingan penggalian nilai-nilai budaya dan proses yang pernah terjadi pada masa lalu dan perkembangannya hingga kini, serta pelestarian benda cagar budaya karena nilainya terhadap suatu peristiwa sejarah yang pernah terjadi pada masa lalu.

Upaya pelestarian situs Ngurawan Kecamatan Dolopo Kabupaten Madiun adalah upaya pelestarian situs Ngurawan Kecamatan Dolopo Kabupaten Madiun demi kepentingan penggalian nilai-nilai budaya dan proses yang pernah terjadi pada masa lalu dan perkembangannya hingga kini serta pelestarian benda cagar budaya karena nilainya terhadap suatu peristiwa sejarah yang pernah terjadi pada masa lalu.

Berangkat dari kesadaran tentang pentingnya memelihara tentang pentingnya memelihara peninggalan-peninggalan sejarah. Situs purbakala peninggalan Kerajaan Glang-Glang ini adalah cerminan tentang kejayaan masa lalu dan untuk membangun masa depan yang lebih baik. Benda-benda yang digunakan oleh nenek moyang dahulu merupakan sumber ilmu pengetahuan. Maka dari itu situs Ngurawan Kecamatan Dolopo Kabupaten Madiun harus dilestarikan. Selain alasan tersebut, bahwa situs Ngurawan Kecamatan Dolopo
Kabupaten Madiun adalah situs kerajaan besar yang tidak kalah penting dengan situs Majapahit dan mempunyai tingkat kerawanan yang cukup tinggi.

\section{Pembahasan}

\section{Situs Ngurawan Kecamatan Dolopo} Kabupaten Madiun (Latar Sejarah dan Upaya Pelestariannya.

Ngurawan atau Wurawan adalah sebutan kuno dari sebuah wlayah yang sekarang berada di daerah Madiun selatan, tepatnya sebuah dusun di Desa Dolopo Kecamatan Dolopo Kabupaten Madiun, yaitu Dusun Ngrawan. Penduduk Dusun Ngrawan mayoritas adalah petani, disamping bertani mereka juga berternak, berkebun dan sebagian membuat batu bata, dalam aktivitas kesehariannya warga sering menemukan berbagai jenis benda purbakala, bahkan di dusun ini batu kuno berukuran besar terlihat banyak berserakan di mana-mana.

Hal ini suatu bukti bahwa Dusun Ngrawan adalah sebuah dusun tua dan pusat peradaban pada masa kerajaan dahulu kala. Dari beberapa peneliti dan berbagai sumber sejarah yang ada menegaskan bahwa dusun Ngrawan adalah pusat kerajaan Glang-Glang $i$ bumi Ngurawan di masa Singhasari dan Kadipaten Gegelang di Masa KerajaanMajapahit. Hal ini tidak termasuk mengganti nama Dusun Ngrawan dengan sebutan lain, namun hanya semata 
menegaskan bahwa dusun Ngrawan adalah titik dari sebuah peradaban kerajaan besar di kala itu, yaitu Kerajaan Glang-Glang $i$ bumi Ngurawan. Di Ngurawan ada sebuah mitos yaitu kutukan yang masih dipercaya hingga saat ini. Sesuai dengan pengertian mitos adalah sebuah cerita rakyat yang dianggap benar-benar terjadi, dan kutukan tersebut akan benar-benar menimpa bagi siapa saja yang melanggarnya.

Seperti yang disampaikan oleh sesepuh dusun ini yaitu Bapak Mulyani, mitos tersebut adalah sebuah sabda bahwa siapapun pejabat pamong praja yang masuk Dusun Ngurawan maka akan menemui celaka, namun juga diceritakan oleh Bapak Mulyani bahwa kutukan tersebut tidak sepenuhnya benar. Contoh sudah ada beberapa pejabat yang masuk dusun ini dengan niat yang baik, namun sebagaian masyarakat Dolopo masih banyak yang percaya bahwa kutukan bagi para pejabat yang masuk dusun Ngurawan ini masih berlaku, terutama bagi mereka yang berniat kurang baik.

Akibat mitos tersebut banyak pegawai pemerintahan atau pejabat daerah yang takut untuk berkunjung ke Dusun Ngrurawan, hingga program pembangunan dusun ini pun kurang terpantau oleh pejabat daerah maupun pusat, termasuk keberadaan situs Ngurawan yang kurang mendapat perhatian dan banyak mengalami kerusakan bahkan hilang. Krom (1954: 145) menyatakan bahwa Glang-Glang sama dengan Daha atau Kadiri. Namun demikian, Poerbatjaraka (1968: 372) tidak sependapat dengan pendapat Krom yang mengemukakan bahwa Glang-Glang tidaklah sama dengan Daha, dalam arti kata yang sesungguhnya dan dalam arti yang terbatas menurut geografis.

Hal tersebut merupakan hasil penelitiannya dalam cerita-cerita Panji dimana terdapat nama Kerajaan Gegelang (Glang-Glang) disamping Kerajaan Daha. Lokasi Gegelang teridentifikasi berada di sebelah barat Gunung Wilis. Poerbatjaraka melokasilisasikan Glang-Glang berada di daerah Pagotan, selatan Kota Madiun. Pelokasian Glang-Glang berada di barat Gunung Wilis didukung oleh beberapa sumber data sejarah sebagai berikut: Cerita Centini memberikan petunjuk yang jelas tentang lokasi Gegelang ketika Panji mengabdi kepada Raja Gegelang.

Sesudah rombongan Raden Jayengresmi, Jayengraga, Kulawirya dan Nurripin sampai di Memenang Kediri. Kemudian mereka bermalam di pelabuhan, di tepi Brantas sebelah timur. Pada keesokan harinya, mereka menyeberangi sungai dengan sebuah perahu tambangan dan menuju ke Gunung Klotok di Gua Selomangleng. Ketika hendak meneruskan perjalanan dari Gua Selomangleng, mereka menanyakan jalan menuju Gegelang. Mereka mendapatkan jawaban, bahwa Gegelang masih jauh. perlu tiga hari lagi perjalanan dari Gua Selomangleng. Menyusuri kaki 
Gunung Wilis di sebelah utara, kemudian berjalan ke barat mengelilingi gunung (Wilis) (Poerbatjaraka,1968: 373).

Daerah-Daerah di sebelah barat Gunung Wilis adalah daerah Karesidenan Madiun. Oleh karena itu, pelokalisasian Gegelang atau Glang-Glang di Madiun tidaklah bertentangan dengan informasi dalam Serat Centini. Selain itu, dalam cerita Panji Malat disebutkan juga tentang orangorang Pagutan yang kaget atas kedatangan orang-orang Melayu ke wilayah Gegelang (Poerbatjaraka, 1968: 315). Dari sinilah Poerbatjaraka mengidentifikasi Glang-Glang sama dengan Pagutan, yang sekarang menjadi Desa Pagotan Kecamatan Geger Kabupaten Madiun

\section{Upaya Pelestarian Situs Ngurawan} Kecamatan Dolopo Kabupaten Madiun

Pelestarian merupakan kegiatan penting dan utama, sebab tanpa pelestarian maka kegiatan pembinaan dan pemanfaatan tidak dapat dilaksanakan. Oleh karena itu, upaya penyelamatan data pelestarian sumber daya arkeologi perlu mendapat perhatian utama untuk dikembangkan dan dimasyarakatkan (Suhartono, 2009: 11). Upaya pelestarian situs diwujudkan dalam beberapa aktivitas pelestarian benda cagar budaya. Pelestarian ini dilakukan dalam bentuk aktvitas. Aktivitas yang tercakup didalamnya meliputi pemeliharaan, perawatan dan pemugaran. Aktivitas pemeliharaan dilakukan antara lain dengan membersihkan dari kotoran debu dan sampah. Aktivitas perawatan dilakukan antara lain dengan mengusahan agar komponen penyusun berada pada posisi yang seharusnya. Sehingga fungsi komponen tersebut dapat diaktualisasikan secara penuh.

Aktivasi pemugaran dilakukan dengan cara membangun kembali sesuai kondisi yang asli oleh karena itu aktivitas pemugaran perlu dilaksanakan apabila ada kerusakan yang sangat parah (Yustinus dalam jurnal Konservasi Benda Cagar Budaya, 2008: 5). Berbicara mengenai pelestarian situs, situs Ngurawan kecamatan Dolopo kabupaten Madiun juga sangat penting untuk dilestarikan. Temuan situs Ngurawan berserakan di pekarangan dan persawahan rumah warga. Kawasan ini semestinya ditetapkan menjadi kawasan cagar budaya agar melindungi peninggalan masa lalu. Hingga kini sisa-sisa peninggalan bersejarah itu teronggok begitu saja.

Tak ada perawatan dan tak ada eskavasi. Pihak arkeologi menurut Widia hanya sekedar tahu saja. Padahal bila melihat area sisa peninggalan kerajaan ini, diperkirakan ada candi dan berbagai sarana kota. Berangkat dari kesadaran tentang pentingnya memelihara peninggalanpeninggalan sejarah. Situs purbakala peninggalan Kerajaan Glang-Glang ini adalah cerminan bagi kita tentang kejayaan masa lalu dan untuk membangun digunakan oleh nenek moyang kita, merupakan sumber ilmu pengetahuan. Maka dari itu situs 
Ngurawan Kecamatan Dolopo Kabupaten Madiun harus dilestarikan selain alasan itu situs Ngurawan kecamatan Dolopo Kabupaten Madiun adalah situs kerajaan besar yang tidak kalah penting dengan situs Majapahit, dan mempunyai tingkat kerawanan yang cukup tinggi. Peninggalan sejarah lokal ini pelestariannya sudah cukup membaik dari tahun ke tahun. masa depan yang lebih baik.

Benda-benda yang berserakan sudah di rawat dengan perawatan yang benar dan bahkan ada salah satu rumah warga yang disumbangkan untuk pelestarian Situs Ngurawan Kecamatan Dolopo serta perawatannya. Selain penanganan dari masyarakat sekitar situs Ngurawan Kecamatan Dolopo Kabupaten Madiun para pecinta sejarah di Madiun secara swadaya melalui LSM Kompas Madya Historia van Madioen menggerakkan minat masyarakat dalam memelihara sejarah daerahnya. Sebuah Festival yang bertempat di desa Ngurawan Kecamatan Dolopo Kabupaten Madiun ini bertujuan untuk melestarikan kebudayaan dan untuk menjaga peninggalan Sejarah di Madiun.

Dengan konsep sinergi antara unsur budaya masyarakat, potensi wisata alam Desa serta pemberdayaan masyarakat lokal sebagai misi dasar pembentukan acara Festival Glang-Glang. Di desa Ngurawan ini dulu masih tersisa reruntuhan istana Glangglang tempat bertahta Prabu Jayakatwang. Sayangnya, reruntuhan tersebut sekarang sudah hampir tak berbekas lagi. Namun berkat usaha masyarakat serta orang-orang yang peduli akan budaya lokal daerah bisa teratasi lebih baik dari pada keadaan sebelumnya. Hal ini dibuktikan antusiasnya dalam pergelaran Festival Glang-Glang untuk berpatisipasi dalam acara pemecahan rekor MURI yang dilaksanakan pada tanggal 18-20 Desember 2014.

\section{Daftar Pustaka}

\section{(Diakses}

http://lokalbahasasastra.blogspot.co $\mathrm{m} / 2012 / 02$ /latar-setting.html 15-042015) 14.00 wib.

(http://digilib.uns.ac.id/dokumen/detail/4 1785/Penerapan-Good-GovernanceDi-Balai-Pelestarian-Situs-ManusiaPurba-Sangiran-Bpsmps-DalamUpaya-Pelestarian-Benda-CagarBudaya-Di-Situs-Sangiran diakses 1504-2015 $02.00 \mathrm{wib}$ ).

(http://digilib.uns.ac.id/dokumen/jenis/10 186/ diakses 15-04-2015 14.00 wib)

(http://digilib.uns.ac.id/dokumen/jenis/10 186/ diakses 15-04-2015 14.00 wib)

(http://melayuonline.com/ind/history/dig/ 3/situs-sejarah diakses 15-04- 2015 09.00 wib)

(http://www.riko.web.id/2013/12/pengert ian-situs-web.html diakses 15-04$201509.00 \mathrm{wib})$

Diakses http://kbbi.web.id/latar 15-04$201514.00 \mathrm{wib})$.

Hamid, R. dan Majid, S. M. 2011. Pengantar Ilmu Sejarah. Yogyakarta: Ombak. 
Hatmadji, T. 1992. Berkala Arkeologi. Тemu Evaluasi Penelitian wonoboyo. Yogyakarta: Balai Arkeologi Yogyakarta.

Kochhar. 2008. Pembelajaran Sejarah Teaching of History.Jakarta: PT Gramedia Widiasarana Indonesia.

Mahmud, I. M. dan Mas'ud, Z. 2002. Warisan Sumber Daya Arkeologi dan Pembangunan. Jayapura: Ombak.

Miles, M. B. dan Hubermen, A.M. 1992. Analisis Data Kualitataif. Jakarta: Universitas Indonesia.

Moleong, L. J. 2012. Metode Penelitian Kualitatif. Bandung: PT Remaja Rosdakarya.

Nazir, M. 2009. Metode Penelitian. Jakarta: Ghalira Indonesia.

Prastyo, Y. dan Wasito, H. H. 2014. Sejarah Tari Keling dan Upaya Pelestariannya (Studi Historis di Dusun Mojo Desa Singgahan Kecamatan Pulung Kabupaten Ponorogo Tahun 19422012). Agastya Jurnal Sejarah dan Pembelajaranya. (Vol.04 No. 01 Januari 2014). Madiun: Program Studi Pendidikan Sejarah.

Purwodarminto, W. J. S. 1976. Kamus Umum Bahasa Indonesia. Jakarta: Pn Balai Pustaka.

Ristian, A. F. dan Soebijantoro. 2014. Cerita Sejarah dan Penanaman Nilai-Nilai Moral (Studi Kasus di Desa Padean Kecamatan Mejayan Kabupaten Madiun). Agastya Jurnal Sejarah dan Pembelajarannya (Vol. 4 No. 01 januari 2014. Madiun: Prodi Pendidikan Sejarah.

Silalahi, A. G. 2003. Metodologi Penelitian dan Studi Kasus. Sidoarjo: CV Citra Media.
Sjamsuddin, H. 1996. Metodologi Sejarah. Yogyakarta: Ombak.

Soebijantoro. 2013. Undang-Undang Cagar Budaya Di Era Otonomi Daerah (Suatu Harapan dan Tantangan). Agastya. Sejarah dan Pembelajaranya. (Vol.04 No. 01 Januari 2014). Madiun: Program Studi Pendidikan Sejarah.

Sugiono. 2013. Metode Penelitian Manejemen. Bandung: Alfabeta.

Sugiyono. 2008. Metode Penelitian Kuantitatif Kualitatif Dan R\&D. Bandung: Alfabeta.

Sugono, D. 2008. Kamus Besar Bahasa Indonesia. Jakarta: PN Balai Pustaka.

Suhartono, Y. 2009. Pelestarian Sumber Daya Arkeologi Dalam Konteks Keruangan di Kawasan Borobudur (Studi Kasus Candi Borobudur, Mendut dan Pawon) .Jurnal konservasi benda Cagar Busaya Borodubur Vol.II No,03. Magelang: Balai Konsorvasi Peninggalan Borobudur

Suranto, Y. 2008. Identifikasi Kayu dan Perannya Terhadap Pelestarian Benda Cagar Budaya. Jurnal konservasi benda Cagar Busaya Borodubur Vol.II No,02. Magelang: Balai Konsorvasi Peninggalan Borobudur.

Sutopo. 2002. Metode Penlitian Kualitatif. Surakarta: Sebelas Maret University Press.

Sutrasno. 1975. Sejarah dsan Ilmu Pengetahuan (History dan Science). Jakarta: Prandaya Paramita.

Tim Kompas Madya. 2014. Ngurawan Mitos dan Sejarah. Madiun: Tim Kompas Madya.

Umar, H. 2011. Metode Penelitian Untuk Skripsi Dan Tesis Bisnis. Jakarta: Rajagrafindo Persada.

Undang Undang Republik Indonesia No. 11 Tahun 2010 Tentang Cagar Budaya.

Usman, H. dan Akbar, S. P. 2003. Metodologi Penelitian Sosial. Jakarta: PT Bumi Aksara. 